\title{
Understanding the Nature and Process of Alternative Dispute Resolution and Collective Conciliation: Lessons from United Kingdom, Canada, South Africa and Japan
}

\author{
Ige, Adejoke Yemisi ${ }^{1}$ \\ ${ }^{1} \mathrm{PhD}$., Department of Employment Relations and Human Resource Management, Faculty of Business \\ Administration, University of Lagos, Akoka, Yaba, Lagos, Nigeria \\ Correspondence: Ige, Adejoke Yemisi, PhD., Department of Employment Relations and Human Resource \\ Management, Faculty of Business Administration, University of Lagos, Akoka, Yaba, Lagos, Nigeria.
}

Received: August 1, 2017

doi:10.5539/ibr.v10n11p103

\author{
Accepted: September 26, 2017 \\ Online Published: October 13, 2017
}

URL: https://doi.org/10.5539/ibr.v10n11p103

\begin{abstract}
This paper presents a systematic investigation into previous studies, conducted among scholars on the nature and process of Alternative Dispute Resolution and collective conciliation in some selected countries. It presents an assessment of previously conducted empirical studies on the factors that shape the nature and process of ADR and collective conciliation. It examines how these factors influence the attitude and opinion of the users of the service and impact on outcomes in practice. The findings of the study illustrate the significance of the state and its machinery in the establishment and funding of ADR institutions. It demonstrate the importance of trade unions and management representatives acknowledging their inability to resolve their dispute and the extent which their request for conciliation indicate their level of trust and confidence in the process as evident in South Africa, the United Kingdom, Canada and Japan. In addition, the findings establish how the behaviour of the state, as reflected through its approach to the employment relationship influences the actions and perception of trade unions and management representatives. The study recommends that in order to further increase the trust and confidence of trade unions and management on the outcomes of dispute resolution, the neutrality and confidentiality of the process of conciliation is essential. The role and style of conciliators during resolution is also important because; it has the tendency to influence the assessment of trade unions and management representatives during negotiation and impact on their attitude to the process and outcomes of conciliation in practice.
\end{abstract}

Keywords: alternative dispute resolution, nature and process of collective conciliation, South Africa, the United Kingdom, Canada, Japan, outcomes

\section{Introduction}

Academic debates on Alternative Dispute Resolution (ADR) and collective conciliation tend to focus on a number of key aspects of conciliation including the contextual and institutional framework that surrounds it (Hawes, 2000; Goodman, 2000) and the personality and role or styles and strategies of conciliators (Dix et al., 2008; Dix and Oxenbridge, 2004). Other studies have reported how the outcomes of conciliation are dependent on the willingness of the parties to engage in negotiation and make compromise (Bond, 2011; Ruhemann, 2010; Dickens, 2000). More recent studies have focused on the attitude of the parties towards each other, the level of their tolerance of the invol vement of an independent third party, and how the action of the parties determines the process and outcomes of conciliation (Broughton and Cox, 2012; Heery and Nash, 2011). None of these studies have presented empirical analysis on the nature and process of collective conciliation hence; this article presents a review of empirical studies on ADR and collective conciliation in some selected context. The assessment is undertaken in order to identify the specific factors (through empirical studies) that are involved in the process and outcomes of ADR and collective conciliation. This paper is divided into five sections and structured as follows: Section two presents the meaning, nature and practice of ADR and collective conciliation in different contexts. Section three then examines the emergence and nature of ADR and collective conciliation in South Africa, the United Kingdom, Canada and Japan. The analysis in this section is grouped into three sub-sections. Firstly, the environmental and institutional factors that shape the nature of collective conciliation is considered; Secondly, the legislative factors that shape the nature and process of collective conciliation are examined; and the third sub-section investigates the emergence 
and nature of ADR and collective conciliation. Section four present explanations on the attitudes and perceptions of the users of collective conciliation, considers the discussion of findings and conclude.

\section{Meaning, Nature and Practice of ADR and Collective Conciliation in Different Contexts}

A critical review of existing literature reveals that conciliation and arbitration have been available to employers and their trade unions in the United Kingdom (UK) since the 1800s, although these processes were in minimal use until the 1970s. Industrial courts and tribunal systems and industrial action were the preferred methods for resolving workplace-related disputes (Van Gramberg et al., 2016; Saundry et al., 2016; Hann et al., 2016; Teague and Roche, 2012; Baker, 2002; Mistelis, 2001; Gould, 1998). The establishment of the Advisory, Conciliation and Arbitration Service (ACAS) in the UK was a key moment in 1975. ACAS was instituted as a publicly-funded independent organisation that performs a wide selection of functions ranging from handling complaints and giving advice to the providing of conciliation and mediation and arbitration services in both the public and private sectors. This non-statutory system of ADR, carried out by ACAS in the UK is not influenced by government policies however; its structure and organisation may be modified or changed by state regulations (Dix and Oxenbridge, 2004; Hawes, 2000; Goodman, 2000). The UK system of conciliation and arbitration shares some features with Canada and Japan. In the 1970s, non-adversarial methods of resolving disputes had been successfully incorporated into the civil procedure system made available for collective dispute resolution in these countries (Forsyth and Smart, 2009; Funken, 2003). The state plays a key role in the formulation of legislation that frames the employment relationship through its contractual dimension and specifically, concerning the recognition and integration of $\mathrm{ADR}$ as an alternative method for resolving workplace disputes (Forsyth and Smart, 2009; Funken, 2003).

ADR does vary in nature, however, in different contexts. Pretorius (1993) describes the rise of ADR institutions in South Africa. According to Pretorius's (1993) study, the legal institutions of South Africa's apartheid government were viewed with a great deal of suspicion by the majority of the population, who had become frustrated and discouraged with the system of court proceedings because a power tussle had become the underlying factor influencing the activities of the parties. ADR processes and their institutions were developed in South Africa in the 1980s. The state has since played a key role, as revealed in its attitude towards trade union and management related issues through the restructuring of the labour laws that make it possible for trade unions to engage with management in collective bargaining and alternative dispute resolution. The situation in South Africa demonstrates how contextual factors within the society translate to the workplace. It indicates how workplace related disputes between trade union and management are perceived and the way in which their perception impacts on the end results of resolution (Nupen, 2014; Bhorat et al., 2009).

In Canada, conciliation and mediation are the primary dispute resolution processes available for the resolution of collective disputes. According to the Federal Mediation and Conciliation Service (FMCS) in Canada, conciliation is conducted by conciliation officers or by a conciliation board appointed by the Minister for Labour. Apart from the conciliation and mediation services provided by the FMCS, private mediation services are widespread in Canada because it is a required step for the parties to take before approaching the court for settlement. Meanwhile in Japan, three methods of ADR are commonplace: conciliation, compromise (a combination of litigation and mediation) and arbitration (Funken, 2003). The importance of the neutrality of ADR institutions while carrying out their responsibilities and the ability of the state to provide financial assistance makes it easy for these ADR institutions to effectively provide voluntary and confidential as well as free services. The key point to note from Canada and Japan's ADR method is that conciliation is in operation and the state is responsible for providing the financial assistance needed by the ADR institutions to maintain their neutrality and provide confidential service to trade unions and management.

\section{Emergence and Nature of ADR and Collective Conciliation}

A range of studies have examined the factors that shape the nature and process of collective conciliation. Goodman's (2000) analysis examined the causes of disputes that are essential while shaping the nature and process of collective conciliation. Goodman's (2000) study in the UK identified the causes as: conflict over the terms and conditions of employment, trade union recognition, redundancy, dismissal and discipline, and changes in working practices. Other empirical studies in the UK (see Hale et al., 2012; Heery and Nash, 2011) have examined the sources of requests for collective conciliation, and the findings reveal both employers and trade unions requests for conciliation, although a joint request for conciliation is becoming common. The findings from studies by Hale $\mathrm{et} \mathrm{al}$. (2012) and Heery and Nash (2011), also in the UK, put forward the idea that there is a rise in the level of awareness and acceptance of collective conciliation in the workplace. Thus, indicating conciliation may in some circumstances provide the platform needed by employers and trade unions to resolve their differences of opinion 
and continue with negotiations without resorting to litigation (Hale et al., 2012; Heery and Nash, 2011; Goodman, 2000).

The role of conciliators has formed the focus of a significant portion of studies of collective conciliation. Some see the role of conciliators as enabling a voluntary settlement between the disputing parties (Hernández et al., 2016; Poole, 2016; Dix, 2000; Lewis, 1982). Others maintain that conciliators carry out their role by acting as intermediaries in the exchange of information and ideas and ensuring that the parties maintain open communications with each other by clarifying issues and establishing mutual grounds for settlement (Clark et al., 2012; Dix and Oxenbridge, 2004; Dix, 2000). Still others find that conciliators are involved in identifying likely barriers to progress by dispelling parties' unrealistic expectations. Furthermore, these studies maintain that conciliators consider with the parties the shortcomings of unresolved disputes, and create reassurance that an acceptable solution will be found (Poole, 2016; Cooper et al., 2016; Goodman, 2000; Kessler, 1980; Goodman and Krislov, 1974).

Many studies (see Dix and Oxenbridge, 2004; Dix, 2000) have described the role of conciliators as providing a calm and informal atmosphere and understanding the difficulties that the parties are faced with and having a knowledge and experience of industrial relations. Conciliators may be able to offer suggestions to the parties about possible solutions by using their experience in a variety of ways specifically to build the confidence of the parties in the process and outcomes of conciliation (Hiltrop, 1985; ACAS Annual Report 2013/14; Dickens, 1979). These roles of conciliators have been grouped into three categories: reflexive, informative and substantive (Dix, 2000). Reflexive roles are concerned with responding to the needs of the parties and establishing a positive working relationship, while at the same time giving the conciliator a better insight and understanding of the case (Kressel and Pruitt, 1989;1985). As information providers, conciliators are required to clarify the details of the case and to convey factual information to the parties. While acting in this capacity, conciliators are required to address discrepancies in the knowledge of the parties and ensure that both sides are equally aware and informed of the legislative dimensions of their case. Conciliators' substantive involvement allows them to move the parties towards resolving their dispute by exploring the strengths and weaknesses of the case. This substantive influence of the conciliator is a common feature of conciliation that allows the conciliator to assess where parties interest lie and to consider what is achievable within the limit of the law to promote settlement (Pruitt and Carne vale, 1993; Hiltrop, 1985).

Following on from the explanations on the categorisation of the roles of conciliators, Dix (2000) maintains that the style of conciliators (reactive-proactive, message bearer-influences, passive- forceful) can have a significant impact on the process and results of conciliation. Conciliators ability to initiate a connection with the parties tends to shape the opinion of the parties about the process of conciliation and have an impact on their view about the approach of the conciliator and the results of conciliation. The conciliators style - message bearing and seeking to influence- relates to the intention of conciliation to provide an open platform for effective communication. This description highlights the duties of the parties and explains the responsibilities of the conciliator during negotiations. Although some conciliators discuss the details of the case and make an effort to influence the decisions of the parties while bearing messages from one party to the other, others simply convey the required information without engaging with the parties. The behaviour of the conciliator during this process can be said to be a reflection of the personality and technique that the conciliator decides to apply at the different stages of the dispute. It suggests the importance of the way in which conciliators present the arguments of each party and how they (the conciliators) strive to gain the confidence of the parties while seeking to influence the effects of negotiations (Dix, 2000).

These different conciliation roles do, it seems, have an impact on the process and outcomes. Conciliators may decide to act their roles out concurrently to fulfill a variety of purposes, particularly as a case progress. The most satisfied service users tend to be those who have experienced more proactive styles of conciliators (Hale, et al., 2012; Dix et al., 2008; ACAS and Ipsos Mori 2006; Dix 2000), which help the parties to rethink their positions on the dispute. In addition to the role of the conciliators, other factors that have a significant impact on the nature and process of end results of conciliation include: the years of experience of the conciliator, the nature of the involvement of the conciliator and training, level of involvement or participation of the conciliator in the practical settlement of the dispute (Gibbons, 2007; Dix and Oxenbridge, 2004; Molloy et al., 2003).

\section{Attitudes and Perceptions of Users of Collective Conciliation}

Several studies have argued that the approach and opinion of the parties about the conciliator and the process of conciliation tend to influence the outcomes of resolutions. For instance, Molloy et al., (2003) claim that conciliation is mostly used by parties in a dispute when they feel that they cannot move forward without assistance 
(Heery and Nash, 2011; Dawe and Neathey, 2008; Dix and Oxenbridge, 2004). Others maintain that parties opt for conciliation when they fail to agree or when negotiations have broken down and internal dispute machineries have been exhausted (ACAS, 2014; ACAS and Ipsos Mori, 2006; Goodman, 2000). Some studies assert that the use of conciliation is informed by the desire of the parties to obtain independent and unbiased assistance (Dix et al., 2008; Molloy et al., 2003; Dix, 2000), while others affirm that the choice of conciliation is mainly due to its being the next step in the dispute procedure, or because the settlement process requires the parties to conciliate before they can proceed to arbitration (ACAS, 2014; Heery and Nash, 2011; ACAS and Ipsos Mori, 2006).

The central point to take note of is the importance of the parties acknowledging their inability to resolve the dispute and their request for third party assistance. Where collective conciliation is not used, this may be attributed to the view that the disputes have not reached a total impasse (Dawe and Neathey, 2008; Molloy et al., 2003). Others affirm that disputing parties do not see what solution conciliators could find that they cannot possibly find themselves (ACAS, 2014; Bond, 2011; ACAS and Ipsos Mori, 2006). Studies assert that disputing parties are of the opinion that it is their job to sort out disputes without bringing in outsiders, hence signifying the parties' perception about the amount of control that conciliators might have over the case and the fact that what might sound reasonable during conciliation might seem very different outside to their members.

The attitude of the parties towards the conciliator and the conciliation process is a crucial factor here. For instance, the use of conciliation could be perceived by some trade unions and management as a sense of personal failure. Others could view the conciliator as an outsider who does not have as much in-depth knowledge about the industry and the peculiarities that exist within the workplace such as the union-management relationship. This description informs the attitude of some trade unions and management representatives who conclude that the role of the conciliator is not important during conciliation (Bond, 2011; Ruhemann, 2010). According to this viewpoint, since the role of the conciliator is limited to facilitating and not making a judgment on the case like arbitrators or judges, then the parties may as well sit back in the comfort of their workplace and proffer solutions to their dispute; especially since the outcome of conciliation needs to be implemented by employers and trade unions and not by the conciliator. This standpoint indic ates that the involvement of conciliators in a collective employment dispute tends to undermine the traditional oppositional dynamics of industrial relations (Bond, 2011; Ruhemann, 2010).

The non-use or low use of collective conciliation can be attributed to fear and anxiety. According to studies by Broughton \& Cox (2012) and Heery and Nash (2011), some employers are of the opinion that by involving conciliators in a collective employment dispute it would result in loss of their control of the settlement process and its possible outcome. This demonstrates the importance of adequate information and education of trade unions and management representatives, as well as other stakeholders that have a role to play in collective conciliation. Training and communication tend to eliminate anxieties and worries by providing opportunities for inquiries to be made about the process and expectations at the end of conciliation. They also provide knowledge of the importance of legislation and the impact of this on negotiations and end results. Additionally, training and communication allow the parties to ask questions and make clarifications which will erase misinterpretation and shape their perception as actors and determine the results of collective conciliation (Broughton and Cox, 2012; Heery and Nash, 2011).

Studies do confirm the importance of the conciliator alongside a host of other institutional and contextual factors in shaping the process and outcomes. For example, an empirical investigation by ACAS and Ipsos Mori (2006) into the settlement rate and satisfaction of disputing parties revealed that $44 \%$ of respondents confirm that conciliators' involvement facilitated the rapid resolution of their case or helped them to move closer towards resolving their dispute. Others reveal that customer satisfaction is particularly high in disputes where most of the key issues were resolved or when some progress was made towards resolution (Booth, et al., 2016; Hale, et al., 2012; Dawe and Neathey, 2008; Hiltrop, 1985). Advocates of this view specify that conciliators who proactively seek agreement with disputing parties record a high rate of satisfaction (Hale, et al., 2012; Dawe and Neathey, 2008). Others establish that the conciliator's ability to identify areas of agreement and disagreement while exploring the parties' points of view on the dispute is also usually associated with a high satisfaction rate. More recent studies that examined the impact of collective conciliation on outcome of disputes and timing of assessment reveal that conciliation has assisted in bringing the parties closer together and has also helped them to avoid industrial action and speed up resolution (Hale, et al., 2012; Heery and Nash, 2011; Bond, 2011; Ruhemann, 2010; Dawe and Neathey, 2008). Still others assert that conciliation has impacted positively on the relationship that exists between the parties and improved the result of the resolution. Studies that considered the impact of conciliators' nonintervention in dispute situations confirm that the case would have resulted in the dispute remaining unresolved or being steered towards industrial action or a strike (Hale et al., 2012; Dawe and Neathey, 2008). The important idea to consider is that irrespective of the approach or style that the conciliator decides to adopt during conciliation the 
principal aim of building a relationship and exploring the parties' points of view on the dispute, then providing a rapid resolution to improve the results is essential for high customer satisfaction rate (Heery and Nash, 2011; Bond, 2011; Ruhemann, 2010).

Effective communication is an important tool for conciliators because at the end of conciliation it is anticipated that the parties understand each other's position and the legislation, and can identify the strengths and weaknesses of their case with a view to making a compromise when necessary for the dispute to be resolved (Meadows, 2007; Molloy et al., 2003). Parties seek the assistance of conciliators when they are apprehensive about the future; as soon as the parties decide to approach conciliation they need to understand the need to de-emphasize the power relationship key features of Collective bargaining and Negotiation (CB and $\mathrm{N}$ ). This is because during conciliation the parties are responsible for proposing solutions that will sustain their relationship. Previous studies assert that instead of the parties maintaining entrenched and deeply-rooted positions during discussions their willingness to negotiate and make concessions is essential, because it has the tendency to facilitate rapid resolution (ACAS, 2014; Hale et al., 2012; Broughton and Cox, 2012; Bond, 2011; Heery and Nash, 2011; Ruhemann, 2010).

\section{Discussion of Findings and Conclusion}

The findings of this study reveal some of the similarities that exist in the nature and process of ADR and collective conciliation in the countries considered. For instance, it has become obvious that ADR institutions in the selected countries are publicly-funded, independent organisations that perform a wide selection of functions such as conciliation, mediation and arbitration services in both the public and private sectors. Assessment of the studies indicates that ADR is a non-statutory and non-adversarial method that provides the platform needed by employers and trade unions to resolve their differences of opinion and continue with negotiations without resorting to litigation. ADR has also been successfully incorporated into the civil procedure system made available for collective dispute resolution within these contexts. Thus, it suggests that the system of ADR is not influenced by government policies however; its structure and organisation may be modified by state regulations as evident in South Africa, the UK, Canada and Japan. The state plays a key role in the formulation of legislation that frames the employment relationship through its contractual dimension and specifically, concerning the recognition and integration of ADR as an alternative method for resolving workplace disputes. This implies that the state plays a significant role in the restructuring of the labour laws that make it possible for trade unions to engage with management in collective bargaining and alternative dispute. The importance of the neutrality of ADR institutions while carrying out their responsibilities and the ability of the state to provide financial assistance makes it easy for these ADR institutions to effectively provide voluntary and confidential as well as free services to trade unions and management representatives especially during dispute resolution. The key point to note from the countries under consideration is that conciliation is in operation within each context considered and the state is responsible for providing the financial assistance needed by the institutions to maintain their neutrality and provide confidential service. The role of the conciliator is important because; $\mathrm{s} / \mathrm{he}$ provides a calm and informal atmosphere required for understanding the difficulties that the parties are faced with during resolution. Conciliators knowledge and experience in industrial relations enables them to offer suggestions to the parties about possible solutions and also build the confidence of the parties in the process and outcomes of conciliation. Be that as it may, this study asserts that irrespective of the approach or style that the conciliator decides to adopt during conciliation the principal aim of building a relationship and exploring the parties' points of view on the dispute, tends to provide a rapid resolution of dispute, increase trade union and management's commitment and support of the process and its outcome in practice.

In conclusion, this paper reveals how the meaning and significance attributed to ADR tends to influence its nature and determine its process as evident in South Africa, the United Kingdom, Canada and Japan. It demonstrates the importance of the role of the state especially in the formulation of legislations that frame the employment relationship, boost the recognition and integration of ADR as an alternative method for resolving workplace disputes, and its impact on the process of negotiations and outcomes of resolution. Another key finding that emerge from the analysis presented in this paper is the impact of the independence and objectivity of ADR institutions while carrying out their responsibilities. Using empirical evidence from the selected countries, this paper shows the extent which state provision of financial support to ADR institutions tends to give an impression among trade unions and management representative about the independence and impartiality of the process of conciliation as well as the objectivity of its outcomes. The importance of conciliator's tool of communication has been emphasized in this study. This study asserts that effective communic ation allows conciliators to reveal to the disputing parties the strengths and weaknesses of their case. Conciliators also share information on each party's position as well as the legislation in the course of communication. While relating with both parties through communication, Conciliators approach and personality tends to influence their choice of words and the extent, 
which this impacts on the parties' willingness to engage in negotiations and make compromise that will facilitate prompt resolution and sustain their existing relationship.

\section{References}

ACAS. (2013/14). Advisory Conciliatory Arbitration Service Annual Report and Account, 2013/14.

ACAS. (2014). Measuring the value and impact of the Advisory Conciliatory Arbitration Service; Acas research publications, www.acas.org.uk/researchpapers, last accessed 13/11/15.

ACAS and Ipsos Mori. (2006). Service user's perceptions of Acas conciliation in Employment Tribunal Cases (2005): Acas Research and Evaluation Section and Ipsos MORI. Ref: 01/06.

Baker, A. (2002). Access vs Process in Employment Discrimination: Why ADR Suits the US but not the UK. Industrial Law Journal, 31(2), 113-134. https://doi.org/10.1093/ilj/31.2.113

Bhorat, H., Pauw, K., \& Mncube, L. (2009). Understanding the efficiency and effectiveness of the dispute resolution system in South Africa: An analysis of CCMA Data. Development Policy Research Unit DPRU Working Paper, (09/137). https://doi.org/10.2139/ssrn.2184182

Bond, C. (2011). Trade unions officers' preferences and attitudes towards dispute resolution: A qualitative follow-up study with non-users of Acas collective conciliation; Acas Research Publications, www.acas.org.uk/researchpapers. Ref 09/11.

Booth, C., Clemence, M., \& Gariban, S., (Ipsos MORI) (2016). Acas Collective Conciliation Evaluation. Acas research publications, www.acas.org.uk/researchpapers. Ref 06/16.

Broughton, A., \& Cox, A. (2012). Public sector employers' attitudes to use of Acas collective conciliation; Acas Research Publications, www.acas.org.uk/researchpapers. Ref 07/12.

Brown, S., Cervenak, C., \& Fairman, D. (1998). Alternative Dispute Resolution Practitioners Guide. Office of Democracy and Governance, Bureau for Democracy, Conflict, and Humanitarian Assistance, US Agency for International Development.

Clark, N., Contrepois, S., \& Jefferys, S. (2012). Collective and individual alternative dispute resolution in France and Britain. The International Journal of Human Resource Management, 23(3), 550-566. https://doi.org/10.1080/09585192.2012.641078

Cooper, L. J., Bognanno, M. F., \& Befort, S. F. (2016). What's the Relationships Between Labour Arbitrators' Backgrounds and Outcomes of Discipline and Discharge Awards? An Empirical Analysis. ABA Journal of Labour and Employment Law, 31(3), 433.

Dawe, A., \& Neathey, F. (2008). Acas conciliation in collective employment disputes; Acas research publications, www.acas.org.uk/researchpapers. Ref 05/08.

Dickens, L. (2000). Doing more with less: Acas and individual conciliation. Employment Relations in Britain, 25, 67-91.

Dickens, L. (1979). Conciliation, mediation, and arbitration in British industrial relations. Industrial relations: A social psychological approach, 289-308.

Dix, G. (2000). Doing it with style: The work of the ACAS conciliator in individual employment rights cases ,in B. Towers and W. Brown (Eds) Employment Relations in Britain. 25 years of the Advisory, Conciliation and Arbitration Service, Wiley: Blackwell: London.

Dix, G., \& Oxenbridge, S. (2004). Coming to the table with Acas: from conflict to co- operation. Employee Relations, 26(5), 510-530. https://doi.org/10.1108/01425450410550482

Dix, G., Forth, J. A., \& Sisson, K. (2008): Conflict at work: The pattern of disputes in Britain since 1980. Acas.

Forsyth, A., \& Smart, H., (2009). Third party intervention reconsidered: Promoting cooperative workplace relations in the new fair work system. Australian Journal of Labour Law, 22, 117-146.

Funken, K. (2003). Alternative Dispute Resolution in Japan. University of Munich School of Law Working Paper No. 24. https://doi.org/10.2139/ssrn.458001

Gibbons, M. (2007). A Review of Employment Dispute Resolution in Great Britain, Department of Trade and Industry, http//www.berr.gov.uk/files/file38516.pdf.

Goodman, J. (2000). "After Building bridges and settling differences: collective conciliation and arbitration under ACAS" in Towers, B and Brown, W. (eds), Employment Relations in Britain: twenty-five years 
Advisory, Conciliation and Arbitration Service, London: Blackwell.

Goodman, J. F. B., \& Krislov, J., (1974). Conciliation in Industrial Disputes in Great Britain: A Survey of the Attitudes of the Parties. British Journal of Industrial Relations, 12(3), 327-351. https://doi.org/10.1111/j.1467-8543.1974.tb00011.x

Gould, N. (1998), September. Alternative dispute resolution in the UK construction industry. In 14th Annual ARCOM Conference: $428-437$.

Hale, C., Barrett, G., Bryce, A., \& Ecorys, U. K. (2012). 2011/12 Acas Collective Conciliation Evaluation; Acas research publications, www.acas.org.uk/researchpapers.Ref 17/12.

Hann, D., Nash, D., \& Heery, E., (2016). Workplace conflict resolution in Wales: The unexpected prevalence of alternative dispute resolution. Economic and Industrial Democracy: 0143831X16663013. https://doi.org/10.1177/0143831X16663013

Hawes, W. R. (2000). Setting the pace or running alongside? ACAS and the changing employment relationships. Employment Relations in Britain, 25, 1-30.

Heery, E., \& Nash, D. (2011). Trade Union Officers and Collective Conciliation a Secondary Analysis, ACAS research paper Ref: 10/11 last accessed 12/12/2015.

Hernández, C. A. M., Solís, L. M. C., Fernández, M. A. M., \& Cisneros-Cohernour, E., (2016). Alternative Dispute Settlement Mechanisms: Towards Restorative Justice in Yucatán, Mexico. US-China Education Review, 6(2), 118-124.

Hiltrop, J. M. (1985). Mediator behaviour and the settlement of collective bargaining disputes in Britain. Journal of Social Issues, 41 (2), 83-99. https://doi.org/10.1111/j.1540-4560.1985.tb00856.x

International Labour Organization. (1997). Consensus Seeking Skills for Third Parties Training Package. http://staging.ilo.org/public/libdoc/ilo/1997/97B09_362_engl.pdf. Last accessed 15/4/2014.

Kessler, S. (1980). The Prevention and Settlement of Collective Labour Disputes in the United Kingdom. Industrial Relations Journal, 11(1), 5-31. https://doi.org/10.1111/j.1468-2338.1980.tb00304.x

Kressel, K., \& Pruitt, D. G. (1985). Themes in the mediation of social conflict. Journal of Social Issues, 41(2), 179-198. https://doi.org/10.1111/j.1540-4560.1985.tb00862.x

Lewis, P. (1982). The role of ACAS conciliators in unfair dismissal cases. Industrial Relations Journal, 13(3), 50-56. https://doi.org/10.1111/j.1468-2338.1982.tb00414.x

Meadows, P. (2007). A review of the economic impact of employment relations services delivered by ACAS; NIESR.

Mistelis, L. A. (2001). ADR in England and Wales. Am. Rev. Int'l Arb., (12):167-441.

Molloy, D., Legard, R., \& Lewis, J. (2003). Resolving Collective Disputes at work: User perspectives of Acas collective conciliation service; Acas research publications, www.acas.org.uk/researchpapers. Ref 01/03.

Nupen, C. (2014). Mediation and conflict resolution in South and Southern Africa: A personal account of the past 30 years. African Journal on Conflict Resolution, 13(3), 85-114.

Podro, S., \& Suff, R. (2005). Making more of alternative dispute resolution. Advisory, Conciliation and Arbitration Service (ACAS).

Poole, R. (2016). Facilitating systemic outcomes through anti-discrimination conciliation and the role of the conciliator in this quest. Australasian Dispute Resolution Journal, 27(1), 49-57.

Pretorius, P. (1993). Dispute Resolution. Journal of the South African Law, 379.

Pruitt, D. G., \& Carnevale, P. J. (1993). Negotiation in social conflict. Thomson Pacific Grove. California. Brooks/Cole Pub. Co

Ruhemann, C. (2010). Trade Union negotiating officials use and non-use of Acas conciliation in industrial disputes; Acas research publications, www.acas.org.uk/researchpapers. Ref 07/10.

Saundry, R., Adam, D., Ashman, I., Forde, C., Wibberley, G., \& Wright, S. (2016). Managing individual conflict in the contemporary British workplace. Acas Research Paper, 02/16.

Teague, P., \& Roche, W. K. (2012). The growing importance of workplace ADR. The International Journal of Human Resource Management, 23(3), 447-458. https://doi.org/10.1080/09585192.2012.641084 
Van Gramberg, B., Teicher, J., \& Bamber, G. (2016). Reshaping the Role of the Tribunal as Third Party in Australian Workplace Conflict Resolution. In Reframing Resolution. United Kingdom. Palgrave Macmillan, 237-263. https://doi.org/10.1057/978-1-137-51560-5_12

\section{Copyrights}

Copyright for this article is retained by the author(s), with first publication rights granted to the journal.

This is an open-access article distributed under the terms and conditions of the Creative Commons Attribution license (http://creativecommons.org/licenses/by/4.0/). 